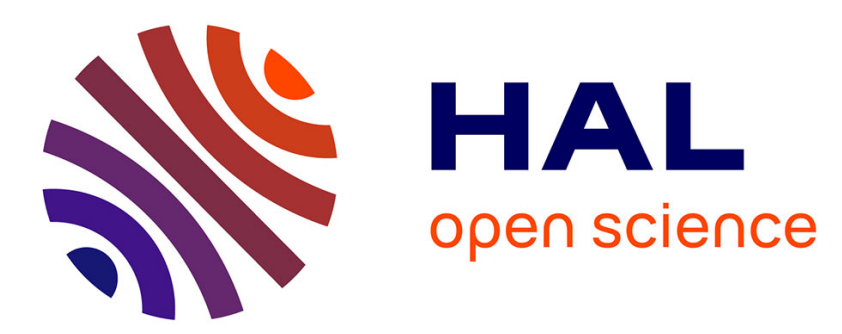

\title{
Stabilizing Effect by Geminal Dioxy Substitution and Anomeric Effect in 3,6-Dihydro-6-methoxy-1,2-oxathiin 2-Oxides
}

Brigitte Deguin, Pierre Vogel

\section{- To cite this version:}

Brigitte Deguin, Pierre Vogel. Stabilizing Effect by Geminal Dioxy Substitution and Anomeric Effect in 3,6-Dihydro-6-methoxy-1,2-oxathiin 2-Oxides. Helvetica Chimica Acta, 1993, 76, pp.2250-2253. hal-01908973

\section{HAL Id: hal-01908973 \\ https://hal.science/hal-01908973}

Submitted on 30 Oct 2018

HAL is a multi-disciplinary open access archive for the deposit and dissemination of scientific research documents, whether they are published or not. The documents may come from teaching and research institutions in France or abroad, or from public or private research centers.
L'archive ouverte pluridisciplinaire HAL, est destinée au dépôt et à la diffusion de documents scientifiques de niveau recherche, publiés ou non, émanant des établissements d'enseignement et de recherche français ou étrangers, des laboratoires publics ou privés. 


\title{
Stabilizing Effect by Geminal Dioxy Substitution and Anomeric Effect in 3,6-Dihydro-6-methoxy-1,2-0xathiin 2-Oxides
}

\author{
by Brigitte Deguin and Pierre Vogel*
}

The hetero-Diels-Alder addition of $\mathrm{SO}_{2}$ to (E)-hexa-1,3-dicne (4) gives first 6-ethyl-3,6-dihydro-1,2-oxalhiin 2-oxide ( = 6-ethykuhine) with the Et group occupying a pseudoaxial position, and then the more stable stereoisomer $f$ with the Et substituent in a pseudoequatorial position. The $\mathrm{SO}_{2}$ additions to 1-methoxybuta-1,3-diene (7) and to 1-methoxy-3-[(trimethy]silyl)oxy]buta-1,3-dicne (8) give the 6-methoxysultines 9 and $\mathbf{1 0}$, respectively, with the $\mathrm{MeO}$ groups in pseudoaxid positions and which do not equilibrate with sultines having pseudoequatorial MeO substituents (anomeric effect). A lower limit of $\Delta \Delta G=3.9 \mathrm{kcal}$ imol was evaluated at $-60^{\circ}$ for the stabilizing effect arsing from the geminal vicinity of a $\mathrm{MeO}$ and sulfinate moiety in 3,6-dihydro-6-methoxy-4-[(trimethylsilyl)oxy]1,2-oxathiin 2-oxids.

At low temperature and in the presence of a suitabic catalyst, simple 1,3-dienes add reversibly to $\mathrm{SO}_{2}$ giving the corresponding 3,6-dihydro-1,2-oxathiin 2-oxides (= sultines) [1]. In the case of $(E)$-piperilene (1), sultine $\mathbf{2}$ with a pseudoaxial Me group is formed at $-80^{\circ}$ (Alder endo rule); at $-60^{\circ}, 2$ is decomposed into $1+\mathrm{SO}_{2}$, and the more stable sultine 3 with the Me substituent in a pseudoequatorial position is formed [1] (Scheme).

Scheme'
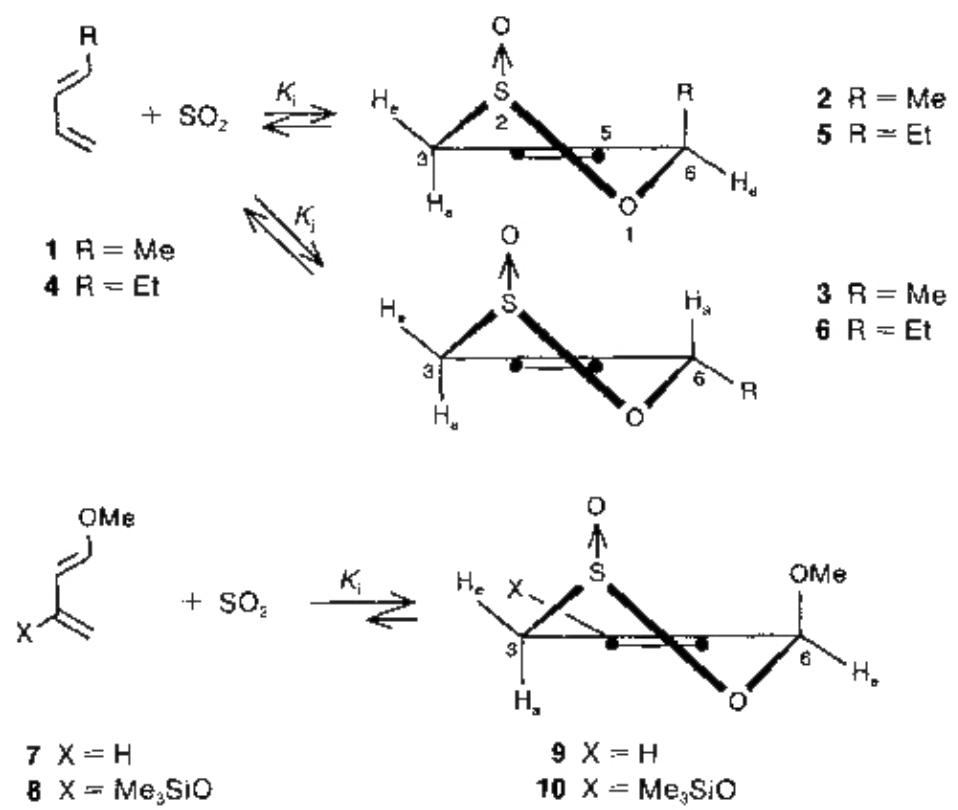
We report here our studies on the hetero-Diels-Alder addition of $\mathrm{SO}$, to $(E)$-hexa-1,3diene (4), $(E)$-1-methoxybuta-1,3-diene (7), and 1-methoxy-3-[(trimethylsilyl)oxy]buta1,3-diene (8). They allow one to establish the existence of a stabilizing effect by geminal dioxy substitution [2] and of an anomeric effect [3] [4] in MeO-substituted sultines.

When mixtures of $4(0.13-0.35 \mathrm{M}), \mathrm{SO}_{2}(4-15 \mathrm{M}), \mathrm{CF}_{3} \mathrm{COOH}(0.18-0.28 \mathrm{M})$, and toluene $\left(0.08-0.18 \mathrm{M}\right.$; internal NMR reference) in $\mathrm{CD}_{2} \mathrm{Cl}_{2}(0.2-0.4 \mathrm{ml})$ were allowed to react at $-80^{\circ}$ (5-mm Pyrex NMR tubes, sealed in vacuo), the sultine 5 was formed in a few $\mathrm{h}$. Raising the temperature to $-60^{\circ}$ led to cycloreversion of 5 into $4+\mathrm{SO}_{2}$ and the formation of the more stable sultine 6. Equilibrium constants $K_{5}=(3-4) \cdot 10^{-3} \mathrm{~mol}^{-7} \mathrm{dm}^{7}$ and $K_{6}=(1.8-6) \cdot 10^{-2} \mathrm{~mol}^{-i} \mathrm{dm}^{3}$ were measured by ${ }^{1} \mathrm{H}-\mathrm{NMR}$ signal integration (toluene as internal reference) for equilibria $4+\mathrm{SO}_{2} \rightleftarrows 5$ and $\mathbf{4}+\mathrm{SO}_{2} \rightleftarrows 6$, respectively, at $-60^{\circ}$. The equilibrium constant did not depend on the amount and concentration of catalyst $\left(\mathrm{CF}_{3} \mathrm{COOH}\right)$ present. Under similar conditions, equilibrium constants $K_{2}=(0.4-$ 1.2) $\cdot 10^{-3} \mathrm{~mol}^{-1} \mathrm{dm}^{3}$ and $K_{3}=(0.4-2) \cdot 10^{-2} \mathrm{~mol}^{13} \mathrm{dm}^{3}$ were evaluated at $-60^{\circ}$ for equilibria $1+\mathrm{SO}_{2} \rightleftarrows 2$ and $1+\mathrm{SO}_{2} \rightleftarrows 3$, respectively. The structure of sultines 5 and 6 were deduced from their ${ }^{1} \mathrm{H}$ - and ${ }^{13} \mathrm{C}-\mathrm{NMR}$ spectra (see Exper. Part) which were very similar to those of 2 and 3, respectively [I]. The pseudoequatorial position of $\mathrm{H}-\mathrm{C}(6)$ in 5 and the pseudoaxjal position of $\mathrm{H}-\mathrm{C}(6)$ in 6 were established by their vicinal coupling constants with $\mathrm{H}-\mathrm{C}(5)$ and their homoallylic coupling constants with $\mathrm{CH}_{2}(3)$ [5].

The 1-methoxybutadienes 7 and 8 were more reactive than 1 and 4 toward $\mathrm{SO}_{2}$ and did not require any acidic catalyst to undergo the hetero-Diels-Alder additions. In the presence of a 70 -fold excess of $\mathrm{SO}_{2}, 0.1-0.2 \mathrm{M} 7$ in $\mathrm{CD}_{2} \mathrm{Cl}_{2}$ (toluene reference, $0.09 \mathrm{M}$ ) led to the quantitative ( $>98 \%$ by ' $\mathrm{H}-\mathrm{NMR}$ ) formation of sultine 9 after $12 \mathrm{~h}$ at $-60^{\circ}$. The latter was stable up to $-20^{\circ}$, temperature at which it was transformed slowly and irreversibly into a mixture of polymeric material. Neither concurrent cycloreversion into $7+\mathrm{SO}_{2}$ nor formation of a stereoisomeric sultine (with pseudoequatorial $\mathrm{MeO}$ group) could be detected at this temperature. An equilibrium constant $K_{9}>3 \mathrm{~mol}^{-1} \mathrm{dm}^{3}$ was estimated for equilibrium $7+\mathrm{SO}_{2} \rightleftarrows 9$. In the presence of a 5-6 fold excess of $\mathrm{SO}_{2}$, the Danishefsky diene 8 gave ( $>98 \%$ by $360-\mathrm{MHz}{ }^{1} \mathrm{H}-\mathrm{NMR}$ ) sultine 10 at $-60^{\circ}$ (after $5 \mathrm{~h}$ ). In this case, an equilibrium constant $K_{10}>40 \mathrm{~mol}^{-1} \mathrm{dm}^{3}$ was evaluated for the hetero-Diels-Alder reaction $8+\mathrm{SO}_{2} \rightleftarrows \mathbf{1 0}$. Neither cycloreversion, nor isomerization to a sultine with a pseudoequatorial $\mathrm{MeO}$ substituent at $\mathrm{C}(6)$ could be detected after prolonged staying of 10 at $-40^{\circ}$. In the presence of a large excess of $\mathrm{SO}_{2}, 10$ was rearranged into 11 which was then slowly decomposed into $(E)$-4-methoxybut-3-en-2-one above $-60^{\circ}$.

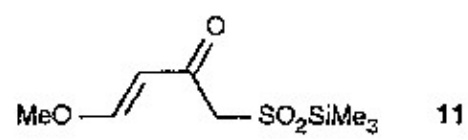

The structures of sultines 9 and 10 were deduced from their ${ }^{1} \mathrm{H}$ - and ${ }^{\text {Li. }} \mathrm{C}$-NMR spectra and with the help of double-irradiation experiments including ${ }^{~} \mathrm{H},{ }^{\prime} \mathrm{H}$ NOE measurements. As for 5 , the pseudoequatorial position of $\mathrm{H}-\mathrm{C}(6)$ in 9 and $\mathbf{1 0}$ was given by its vicinal coupling constant with $\mathrm{H}-\mathrm{C}(5)$ and its homoallylic coupling constants with $\mathrm{CH}_{2}(3)$. The axial position of the $S \rightarrow O$ moiety [4b] was not established unambiguousiy').

5) Commercial (E)-1-methoxybuta-1,3-djene contains 5-10\% of the (Z)-isomer. This reacted also with sO, giving sultine 9, whereas (Z)-hexa-1,3-diene did not add to $\mathrm{SO}_{2}$ between -80 and $20^{\circ}$. 
On comparing equilibrium constants $K_{10}$ and $K_{5}\left(K_{10} / K_{5}>10^{4}\right)$, a lower limit $\Delta \Delta G=3.9 \mathrm{kcal} / \mathrm{mol}$ was calculated at $-60^{\circ}$ for the stabilizing effect resulting from the geminal vicinity of a $\mathrm{MeO}$ and a sulfinate moiety. Assuming that there are no significant differential entropy or/and solution effects on equilibria $4+\mathrm{SO}_{2} \rightleftarrows \mathbf{5}$ and $\mathbf{8}+\mathrm{SO}_{2} \rightleftarrows \mathbf{1 0}$, the geminal dioxy substitution effect evaluated above is comparable to that found for the following isodesmic reaction on comparing the standard heats of formation of products and reactants [6].

$$
2 \mathrm{Me}_{2} \mathrm{CH}(\mathrm{OMe}) \Rightarrow \mathrm{Me}_{3} \mathrm{CH}+(\mathrm{MeO})_{2} \mathrm{CHMe} \Delta H_{\mathrm{t}}^{\circ}=-5.4 \mathrm{kcal} / \mathrm{mol}
$$

The anomeric effect in sultines 9 and 10 (preference for the pseudoaxial rather than pseudoequatorial position for the $\mathrm{MeO}$ substituent) can be compared with the wellknown Edward-Lemieux anomeric effect [3] in methyl pyranosides [4].

We thatk F. Hoffmann-La Roche AG, Basel, the Fonds Herbefte, Lausaune, and the Swiss National Science Foundation for financial support.

\section{Experimental Part}

General. See [7].

NMR Sample Prepartion. $\mathrm{CD}_{2} \mathrm{Cl}_{2}$ and toluene were distilled over anh. $\mathrm{Cali}_{2}, \mathrm{CF}_{3} \mathrm{COOH}$ over $\mathrm{P}_{2} \mathrm{O}_{5}, \mathrm{SO}_{2}$ was filtered through a column of alcaline aluminium oxide 90 (act. L, Merch) before use. It a weighed, dry 5-mm NMR Pyrex tube, diene 4 (15.6 mg, $0.19 \mathrm{mmol})$, c.g., toluene ( $9.2 \mathrm{mg}, 0.1 \mathrm{mmol}$; internal ref.), $\mathrm{CD}_{2} \mathrm{Cl}_{2}(238 \mathrm{mg})$, and $\mathrm{CF}_{3} \mathrm{COOH}$ ( $12.5 \mathrm{mg}, 0.11 \mathrm{~mm}$ - $;$ catalyst) wre mixed under Ar. The soln. was degassed by several freeze-thaw cycles at $10^{-5}$ Torr. Degassed $\mathrm{SO}_{2}$ (ca. $0.33 \mathrm{ml}$ ) was transferred to the above mixture on the vacuum line. The NMR tube was sealed under vacuum. The NMR tube, frozen in liq. $\mathrm{N}_{2}$, was warmed up $10-100^{\circ}$ in $\mathrm{EtOH} / \mathrm{lig} . \mathrm{N}_{2}$ and transferred into the Bruker ( $360 \mathrm{MHz}$ ) probe cooled to $-90^{\circ}$. The first NMR spectrum was recorded at $-80^{\circ}$, temp. at which 5 was tormed. Raising the temp. to $-60^{\circ}$ induced a loss of 5 and formation of 6 . After $10 \mathrm{~h}$ at $-60^{\circ}$, the equilibrium was reached: $4 \%$ of $5,19 \%$ of 6 , and $77 \%$ of 4 . The volume of the soln. (calibrated NMR tube) was $0.54 \mathrm{ml}$. After the NMR experiments, the NMR tube was allowed to reach r.t. and weighed together with the piece of tube left over after the sealing: thus, the exact amount of $\mathrm{SO}_{2}$ introduced in the soln. was measured (480.5 mg, $7.5 \mathrm{mmol}$ ). In that experiment, $K_{5}=3 \cdot 10^{-3} \mathrm{~mol}^{-1} \mathrm{dm}^{3}$ and $K_{6}=1.8 \cdot 10^{-2} \mathrm{~mol}^{-1} \mathrm{dm}^{3}$ were evaluated at $-60^{\circ}$. The equilibrium constants were evaluated for at least three different NMR samples and had reproducible values within experimental error'.

Datu of (2RS,6 RS )-6-Ethy-3,6-dihydro-1,2-oxathin 2-Oxide (5). ${ }^{1} \mathrm{H}-\mathrm{NMR}\left(360 \mathrm{MHz}, \mathrm{CD}_{2} \mathrm{Cl}_{2}\right.$ iSO $\left.\mathrm{SO}_{2}-80^{\circ}\right)$ : $6.20(\mathrm{H}-\mathrm{C}(5)) ; 5.80(\mathrm{H}-\mathrm{C}(4)) ; 4.45(\mathrm{H}-\mathrm{C}(6)) ; 3.38\left(\mathrm{H}_{\mathrm{c}}-\mathrm{C}(3)\right) ; 3.28\left(\mathrm{H}_{\mathrm{a}}-\mathrm{C}(3)\right) ; 1.65,0.83(\mathrm{Et}) ;{ }^{2} J(3 \mathrm{a}, 3 \mathrm{e})=16.5$, ${ }^{3} J(3 e, 4)=7,{ }^{3} /(3 \mathrm{a}, 4)=3,{ }^{3} J(4,5)=11,{ }^{3} /(5,6 \mathrm{e})=2,{ }^{3} J(6 \mathrm{e}, \mathrm{MeCH})=6,{ }^{3} J\left(\mathrm{MeCH}_{2}, \mathrm{MeCH}_{2}\right)=7,{ }^{4} J(3 \mathrm{e}, 5)<0.5$, ${ }^{4} /(3 \mathrm{a} .5)=2.5^{4} J(4,6 \mathrm{e})=3,{ }^{5} J(3 \mathrm{e}, 6 \mathrm{e}) \approx 0.5,{ }^{5} J(3 \mathrm{a}, 6 \mathrm{e})=3.5{ }^{17} \mathrm{C}-\mathrm{NMR}\left(100.63 \mathrm{MHz}, \mathrm{CD}_{2} \mathrm{Cl}_{2} / \mathrm{SO}_{2},-80^{\circ}\right) ; 135.5$ $\left(d,{ }^{\prime} J(\mathrm{C}, \mathrm{H})=157, \mathrm{C}(5)\right) ; 114.1\left(d,{ }^{\prime} J(\mathrm{C}, \mathrm{H})=171, \mathrm{C}(4)\right) ; 79.2\left(d,{ }^{\prime} J(\mathrm{C}, \mathrm{H})=153, \mathrm{C}(6)\right) ; 44.8\left(t,{ }^{1} J(\mathrm{C}, \mathrm{H})=140\right.$, $\mathrm{C}(3)): 29.3\left(t,{ }^{\prime} J(\mathrm{C}, \mathrm{H})=125, \mathrm{CH}_{2}\right) ; 9.3\left(4,{ }^{1} J(\mathrm{C}, \mathrm{H})=120, \mathrm{Me}\right)$.

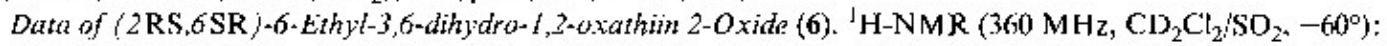
$5.80(\mathrm{H}-\mathrm{C}(5)) ; 5.70(\mathrm{H}-\mathrm{C}(4)) ; 4.55\left(\mathrm{H}_{\mathrm{a}}-\mathrm{C}(6)\right) ; 3.45\left(\mathrm{H}_{\mathrm{u}}-\mathrm{C}(3)\right) ; 3.00\left(\mathrm{H}_{\mathrm{c}}-\mathrm{C}(3)\right) ; 1.7,1.6(\mathrm{MeCH}) ; 0.8\left(\mathrm{MeCH}_{2}\right)$; ${ }^{2} J\left(\mathrm{MeC} / H_{2}\right)=15,{ }^{2} J(3 \mathrm{a}, 3 \mathrm{e})=17.5,{ }^{3} J(3 \mathrm{e}, 4)=6.0{ }^{3} J(3 \mathrm{a}, 4)=2.5,{ }^{4} /(3 \mathrm{c}, 5)=1.0,{ }^{4} J(3 \mathrm{a}, 5)=2.5,5 J(3 \mathrm{a}, 6 \mathrm{a})=4.5$, ${ }^{5} J(3 \mathrm{e}, 6 \mathrm{a})=3.0,{ }^{3} J\left(6 \mathrm{a}, \mathrm{MeCH}_{2}\right)=5.0,7.5,{ }^{3} J\left(\mathrm{MeCH}_{2}, \mathrm{MeCH}_{2}\right)=7,7.5 .{ }^{13} \mathrm{C}-\mathrm{NMR}\left(100.62 \mathrm{MHz}, \mathrm{CD}_{2} \mathrm{Cl}_{2 i}\right.$ $\left.\mathrm{SO}_{2:}-60^{\prime}\right): 132.0\left(d,{ }^{l} J(\mathrm{C}, \mathrm{H})=152, \mathrm{C}(5)\right) ; 114.5\left(d,{ }^{1} J(\mathrm{C}, \mathrm{H})=175, \mathrm{C}(4)\right) ; 7\left(1.4\left(d,{ }^{\prime} J(\mathrm{C}, \mathrm{H})=148, \mathrm{C}(6)\right) ; 45.3(t\right.$, $J(\mathrm{C}, \mathrm{H})=140, \mathrm{C}(3)) ; 26.3\left(t,{ }^{l} J(\mathrm{C}, \mathrm{H})=125, \mathrm{MeCH}_{2}\right) ; 8.3\left(q^{l}{ }^{l} /(\mathrm{C}, \mathrm{H})=120, \mathrm{MeCH}_{2}\right)$.

Data of (2RS,6SR;-3,6-Dihydro-6-methoxy-1,2-oxathin 2-Oxide (9). ${ }^{1} \mathrm{H}-\mathrm{NMR}\left(360 \mathrm{MHz} \mathrm{CO}_{2} \mathrm{Cl}_{2} / \mathrm{SO}_{2}\right.$, $\left.-60^{\circ}\right): 6.18(\mathrm{H}-\mathrm{C}(4)) ; 5.95(\mathrm{H}-\mathrm{C}(5)) ; 4.65\left(\mathrm{H}_{\mathrm{c}}-\mathrm{C}(6)\right) ; 3.65\left(\mathrm{H}_{\mathrm{a}}-\mathrm{C}(3)\right) ; 3.55\left(\mathrm{H}_{\varepsilon}-\mathrm{C}(3)\right) ; 3.46(\mathrm{MeO}) ;$ ${ }^{2} J(3 \mathrm{a}, 3 \mathrm{e})=17.5, \quad 3 J(4,5)=9.0, \quad{ }^{3} J(3 \mathrm{a}, 4)=2.5, \quad{ }^{3} J(3 \mathrm{c}, 4)=3, \quad{ }^{3} J(5,6 \mathrm{c})=3.0, \quad{ }^{4} J(3 \mathrm{e}, 5)={ }^{4} J(3 \mathrm{a}, 5)=2.5$, ${ }^{4} J(4,6 \mathrm{e})=1.5,{ }^{5} J(3 \mathrm{a}, \mathrm{fe})=1.0,{ }^{5} J(3 \mathrm{c}, 6 \mathrm{e}) \leqslant 1 .{ }^{13} \mathrm{C} \cdot \mathrm{NMR}\left(100.62 \mathrm{MHz}, \mathrm{CD}_{2} \mathrm{Cl}_{2} \mathrm{SOO}_{2},-60^{\circ}\right): 129\left(d,{ }^{1} /(\mathrm{C}, \mathrm{H})=177\right.$, $\mathrm{C}(4)) ; 126(d, \quad J(\mathrm{C}, \mathrm{H})=174, \mathrm{C}(5)) ; 97(d, \quad \mathrm{~J}(\mathrm{C}, \mathrm{H})=164, \mathrm{C}(6)) ; 58\left(\mathrm{a}, \quad{ }^{\mathrm{t}} J(\mathrm{C}, \mathrm{H})=145, \mathrm{MeO}\right) ; 53.5(t$, $J(C, \mathrm{H})=145, \mathrm{C}(3))$.

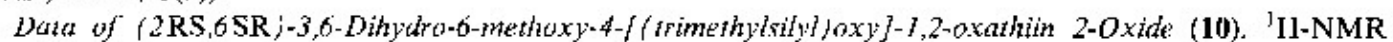
$\left.(360 \mathrm{MHz}, \mathrm{Cl})_{2} \mathrm{Cl}_{2}: \mathrm{SO}_{2},-60^{\circ}\right): 4.82(\mathrm{H}-\mathrm{C}(4)) ; 4.75\left(\mathrm{H}_{\mathrm{e}}-\mathrm{C}(6)\right) ; 3.65\left(\mathrm{H}_{\mathrm{a}}-\mathrm{C}(3)\right) ; 3.40\left(\mathrm{H}_{\mathrm{e}}-\mathrm{C}(3)\right) ; 3.43(\mathrm{MeO}) ; 0.15$ 
$\left(\mathrm{Me}_{3} \mathrm{Si}\right):{ }^{2} J(3 \mathrm{a}, 3 \mathrm{e})=16,{ }^{3} J(5,6 \mathrm{e})=3,0,{ }^{4} J(3 \mathrm{e}, 5)=1.5,{ }^{4} J(3 \mathrm{a}, 5)=2.0,{ }^{5} J(3 \mathrm{a}, 6 \mathrm{e})=1.5,{ }^{5} J(3 \mathrm{e}, 6 \mathrm{e})<0.5 .{ }^{13} \mathrm{C}-\mathrm{NMR}$ $\left(100.62 \mathrm{MHz}, \mathrm{CD}_{2} \mathrm{Cl}_{2} \mathrm{SO}_{2},-60^{\circ}\right): 151(s, \mathrm{C}(4)) ; 99\left(d,{ }^{\prime} J(\mathrm{C}, \mathrm{H})=170, \mathrm{C}(5)\right) ; 97(d, j J(\mathrm{C}, \mathrm{H})=160, \mathrm{C}(6)) ; 59(q$. $\left.{ }^{1} J(\mathrm{C}, \mathrm{H})=145, \mathrm{McO}\right) \div 54\left(t,{ }^{1} J(\mathrm{C}, \mathrm{H})=145, \mathrm{C}(3)\right) ; 0.65\left(q,{ }^{l} J(\mathrm{C}, \mathrm{H})-119, \mathrm{Me}_{3} \mathrm{Si}\right)$.

Data of Trimethylsilyt ( E)-4-Methoxi-2-oxobut-3-enesulfinate (11). Oil. Unstable at $20^{\circ}$, can be stored in soln. al -20 ${ }^{1}{ }^{1} \mathrm{H}-\mathrm{NMR}\left(250 \mathrm{MHz}, \mathrm{CDCl}_{3}\right) ; 7.5\left(d,{ }^{3} J=11, \mathrm{H}-\mathrm{C}(4)\right) ; 5.6\left(d,{ }^{3} J=\mathrm{Il}, \mathrm{H}-\mathrm{C}(3)\right) ; 3.72(s, 2 \mathrm{H}-\mathrm{C}(1)) ; 3.69$ $(s, \mathrm{McO}) ; 0.9\left(s, \mathrm{Mc} \mathrm{q}_{\mathrm{Si}}\right) .{ }^{17} \mathrm{C}-\mathrm{NMR}\left(62.9 \mathrm{MHz}, \mathrm{CDCl}_{3}\right): 190(s, \mathrm{C}(2)) ; 166(d, \gamma(\mathrm{C}, \mathrm{H})=\mathrm{I} 75, \mathrm{C}(4)) ; 107(d$, $\left.{ }^{\prime} J(\mathrm{C}, \mathrm{H})=157, \mathrm{C}(3)\right) ; 69\left(t,{ }^{1} J(\mathrm{C}, \mathrm{H})=140, \mathrm{C}(\mathrm{I})\right) ; 57\left(q,{ }^{1} J(\mathrm{C}, \mathrm{H})=140, \mathrm{MeO}\right) ; 0\left(q,{ }^{7} J(\mathrm{C}, \mathrm{H})=140, \mathrm{Me}_{3} \mathrm{Si}\right)$.

\section{REFERENCES}

[1] B. Deguin, P. Vogel, J. Am. Chem. Soc. 1992, I14,9210.

[2] H.-D. Beckhaus, B. Dogan, S. Verevkin, J. Hädrich, C. Rüchardt, Angew, Chem. Int. Ed. 1990, 29, 320; S. Hati, D. Datta, J. Org. Chem. 1992, 57, 6056, and ref. cit. therein.

[3] J.T. Edward. Chem. Ind. (London) 1955, 1102; R. U. Lemieux, N.J. Chu, Abst. Papers Am, Chem, Soc. Meeting 1958, $133,31 \mathrm{~N}$.

[4] a) A.J. Kirby, "The Anomeric Effect and Related Stereoclectronic Effects at Oxygen', Springer, Berlin, 1983; P. Deslongchamps, 'Stereoelectronic Effects in Organic Chemistry', Wiley, New' York, 1983; b) E. Juaristi, G. Cuevas, Tetrahedron 1992, 48, 5019; c) K. B. Wiberg, M. A. Murcko, J. Am. Chem. Soc. 1989, 111, 4821: K. B. Wiberg, P. R. Rablen, ihid. 1993, 15, 614; d) M. C. Krol, C. J. M. Huige, C. Allona, J. Comput. Chem. $1990,11,765$.

[5] M. Barfield, S. J. Sternhel], J. Am. Chem. Sor. 1972, 94, 1905; M. Barfield, M. Karplus, ibid. 1969, 91, 1; I. Kowalewski, Prog. NMR Spectrose. 1978, 9, 1; C. Mahaim, P.-A. Carrupt, P. Vogcl, Helv. Chim. Acta 1985, 68,2182 .

[6] J. D. Cox, G. Pilcher, 'Thermochemistry of Organic and Otganometallic Cotnpounds', Academic Press, New York, 1970

[7] J. Wagner, E. Vieira, P. Vogel, Heiv. Chim. Acta 1988, 7], 624. 